\title{
Behavior of Flagella and Eyespot during Fertilization of Anisogametes in Caulerpa racemosa (Forsskål) J. Agardh var. laetevirens (Montagne) (Ulvophyceae, Chlorophyta) Revealed by Field Emission Scanning Electron Microscopy
}

\author{
Shinichi Miyamura* \\ Graduate School of Life and Environmental Sciences, University of Tsukuba, Tsukuba, Ibaraki, 305-8572 Japan
}

Received January 13, 2005; accepted January 28, 2005

\begin{abstract}
Summary Respective fates of male and female flagella and the eyespot during fertilization of ulvophycean alga Caulerpa racemosa (Forsskål) J. Agardh var. laetevirens (Montagne) were studied using field emission scanning electron microscopy (FE-SEM). FE-SEM allowed visualization of the eyespot of the biflagellate gamete. The female gamete has one eyespot on a posterior position of the cell body; the male gamete does not. The female gamete eyespot was oriented to the direction of the plane of the flagellar beat. The female gamete is larger than the male one and has the only eyespot. For those reasons, the author followed the fate of the flagella and eyespot during fertilization. When both gametes were mixed, the initial cytoplasmic contact and cell fusion between them usually took place at the anterior end slightly below the flagellar base. In most mating pairs, the female gamete fuses at the left side of the eyespot and male gamete at a cell surface that is perpendicular to the plane of the flagellar beat. As fusion proceeds, the gamete pair is transformed into a quadriflagellate planozygote in which two flagella each from the male and female gametes point in nearly the same direction. In particular, the no. 2 flagellum of the female gamete and one male flagellum were directed to the eyespot. These observations indicated that cell fusion at the particular area of the gamete is important for proper arrangement of the flagella and eyespot in the planozygote.
\end{abstract}

Key words Caulerpa, Eyespot, Fertilization, Flagella, Gamete, Planozygote.

In isogamous and anisogamous green algae, fusing gametes usually become entangled in their flagella and frequently meet end to end. Nevertheless, in most cases, the two cells subsequently become laterally apposed to one another: fusion occurs in this position (Fritsch 1935). The cell fusion sites of gametes in some green algae have been observed with electron microscopy to be differentiated to specialized cell membrane (Chlamydomonas reinhardtii Dangeard; Friedmann et al. 1968, Cavalier-Smith 1975, Goodenough and Weiss 1975, Ch. moewusii Gerloff; Triemer and Brown 1975, Hydrodictyon reticulatum (L.) Lagerh.; Marchant and Pickett-Heaps 1971). In Ch. reinhardtii, this portion of the plasma membrane is designated as the "mating structure" (Goodenough and Weiss 1975). This structure has been reported in subsequent studies of other green algae (e.g., Melkonian 1980, 1981, O'Kelly et al. 1984, Hori 1988), but it has not been found in some green algae (Gaffal and Schneider 1978, Roberts et al. 1981).

The mating structure occupies a specific locale in the gamete (Goodenough and Weiss 1978, Melkonian 1984). Its position is presumably defined by microtubular roots that radiate out from the basal bodies (Ch. reinhardtii; Goodenough and Weiss 1978, Ulva lactuca L.; Melkonian 1980, Bryopsis lyngbyei Hornemann (female gamete); Melkonian 1981, Ulvaria obscura (Kutz.) Gayral var. blyttii (Aresch.) Blid., Monostroma bullosum (Ruth) Thur., M. greville (Thur.) Wittr., M. oxyspermum (Kutz.) Doty; O’Kelly et al. 1984, Spongomorpha duriuscula (Ruprecht) Collins; Miyaji and

* Corresponding author, e-mail: miyamura@sakura.cc.tsukuba.ac.jp 
Hori 1984, Collinsiella cava (Yendo) Printz; Nakayama and Inouye 2000 and Bolbocoleon piliferum N. Pringsheim; O'Kelly et al. 2004). All mating structures that have been investigated ultrastructurally have been linked to one type of microtubular root: the $\mathrm{d}$ root.

In Ch. reinhardtii, the mating type plus structure is associated with the $2 \mathrm{~d}$ root, whereas the minus structure is in contact with the 1d root, creating an asymmetric localization of the mating structure or the cell fusion site (Holmes and Dutcher 1989). Similar asymmetry has been observed in other green algae including Co. cava (Nakayama and Inouye 2000), Ulva arasakii Chihara (Miyamura et al. 2003), Enteromorpha compressa (L.) Nees (Miyamura 2003), Bo. piliferum (O'Kelly et al. 2004), and Nephroselmis olivacea Stein (Suda et al. 2004).

As an explanation for the asymmetric arrangement of the cell fusion site, Holmes and Dutcher (1989) speculated that this asymmetry ensures that the gamete fuse with a fixed polarity such that their two eyespots - one each from a male and a female gamete - lie on the same side of the zygote, and that phototactic steering mechanisms (Kamiya and Witman 1984) are not compromised.

Furthermore, in Bryopsis maxima Okamura, in which the male gamete has no eyespot, cell fusion usually occurs between the anterior left side of the eyespot in the female gamete and a broader face of the male gamete (Miyamura et al. 2005). This observation suggests the possibility that the cell fusion site of the gamete occupies a specialized position even if one gamete does not have an eyespot. However, this possibility has not been substantiated in other green algae in which only the female gamete has the eyespot.

Caulerpa racemosa (Forsskål) J. Agardh var. laetevirens (Montagne) is a monoecious species of ulvophycean siphonous alga that lives in the littoral zone of the tropical and temperate coast. The matured thallus of this alga releases anisogamous gametes, in which only the female gamete has an eyespot (Enomoto and Ohba 1987). Therefore, in this study, the author observed fertilization of C. racemosa var. laetevirens using field emission scanning electron microscopy.

Materials and methods

\section{Plant material}

Thalli of Caulerpa racemosa (Forsskål) J. Agardh var. laetevirens (Montagne) were collected at Amami-Oshima, Kagoshima Prefecture, Japan, between June 2003-June 2004. Samples were brought back to the laboratory and kept in a tank of seawater provided with air through diffusers under natural daylight conditions for several days. Subsequently, each thallus was placed in a separate vessel containing seawater and was maintained under a $12: 12$ light/darkness photoregime, ca. $30 \mu \mathrm{mol} / \mathrm{m}^{2} / \mathrm{s}$, at $22^{\circ} \mathrm{C}$ until liberation of the gametes. Within one month of collection, cytoplasm of all parts of a thallus, except in most of the rhizoidal portion, began to accumulate to form a network. Viscous material containing biflagellate male and female gametes was released through discharge tubes and precipitated on the bottom of the vessel. Male and female gametes mated immediately after discharge.

\section{Scanning electron microscopy}

One volume of sediment containing male and female gametes were mixed on a Nuclepore polycarbonate membrane (Whatman Japan KK, Tokyo, Japan) which was coated with $0.1 \%$ poly (L)-lysine (Sigma Chemical Co., St. Louis, MO, USA) and fixed with one volume of fixatives (6\% glutaraldehyde, $3 \% \mathrm{NaCl}, 0.1 \mathrm{M}$ cacodylate buffer, adjusted to $\mathrm{pH} 7.1)$ at $0,1,5,10 \mathrm{~min}$ after mixing. Cells were fixed for $1 \mathrm{~h}$ at room temperature. After removing the supernatant, the cells on the membrane were fixed with fixatives ( $3 \%$ glutaraldehyde, $3 \% \mathrm{NaCl}, 0.05 \mathrm{M}$ cacodylate buffer, adjusted to $\mathrm{pH}$ 7.1) for $1.5 \mathrm{~h}$ and then washed in a series of $0.05 \mathrm{M}$ cacodylate buffer solutions containing 3,2, 1 , and $0 \% \mathrm{NaCl}$; each step took 30 min. Post-fixation was made in $1 \% \mathrm{OsO}_{4}$ dissolved in $0.05 \mathrm{M}$ cacodylate buffer, $\mathrm{pH} 7.1$, overnight at $4^{\circ} \mathrm{C}$. After dehydration through a graded 
series of ethanol, the cells were infiltrated with t-butyl alcohol, freeze-dried at $4{ }^{\circ} \mathrm{C}$ with a freezedryer (VFD-21S; Vacuum Device Corp., Ibaraki, Japan) and coated with platinum-palladium in a Hitachi ion sputter-coating unit E102 (Hitachi High-Technologies Corp., Tokyo, Japan). Observations were made at $5 \mathrm{kv}$ using a JSM6330F field emission scanning electron microscope (JEOL, Tokyo, Japan). The SEM images were exported to Adobe Photoshop and mounted using Adobe Illustrator. After preparation for FE-SEM, the cells were ca. $72 \%$ the size of living cells.

\section{Results and discussion}

Gametes of Caulerpa racemosa (Forsskål) J. Agardh var. laetevirens (Montagne) were pear-shaped (Figs. 1 and 2). The anterior end of the gametes displayed a papilla with two isokont flagella protruding from its opposite sides (Figs. 1 and 2). In accordance with other recorded cases of anisogamy, the smaller cells will be regarded as "male" while the larger will be "female". Measurement by FE-SEM showed that male gametes were $4.5 \pm 0.4 \mu \mathrm{m}$ (mean $\pm \mathrm{SD})(\mathrm{n}=50)$ long and $1.8 \pm 0.2 \mu \mathrm{m}(\mathrm{n}=50)$ wide; female gametes were $5.5 \pm 0.4 \mu \mathrm{m}(\mathrm{n}=50)$ long and $2.2 \pm 0.2 \mu \mathrm{m}$ $(n=50)$ wide. In both gametes, the anterior end of the papilla was depressed, forming a groove (arrows in Figs. 1 and 2). The groove was oriented roughly perpendicular to the plane of the beat of the flagella.

The female gamete has an eyespot; the male does not (Enomoto and Ohba 1987, Figs. 1 and 2). Its position in the female gamete is easily recognizable using FE-SEM (Fig. 2) because of its oval shape and smooth surface (Hori 1981). Using FE-SEM, one can faintly ascertain the lipid globules that comprise the eyespot (Fig. 3). They are located directly beneath the cell membrane and two chloroplast envelopes.

The eyespot is on one side of the cell; it is posterior of the female gamete correspondent to the plane of the beat of the flagella. The long axis of the eyespots is always parallel to the longitudinal axis in female gametes (Fig. 2). A streak extends down to the cell posterior from the flagellar base and attaches to the left side of the eyespot (arrowheads in Figs. 2 and 3). This streak may correspond to the $2 \mathrm{~s}$ root because the gamete of Caulerpa has four cruciately arranged microtubular root system. In addition, its eyespot is associated with the $2 \mathrm{~s}$ and $2 \mathrm{~d}$ root (Hori 1981), which extends down to the cell posterior from the basal body and is located directly beneath the cell membrane, as in other siphonous green algae (Melkonian and Robenek 1984, Kreimer 2001). Therefore, the left and right flagella in Fig. 2 correspond respectively to no. 1 and no. 2 flagella in the numbering convention of Moestrup and Hori (1989). This numbering of flagella is based on the eyespot position, which is probably consistent in advanced chlorophytes (Melkonian and Robenek 1984, Holmes and Dutcher 1989, Melkonian 1989, Kreimer 2001). However, this numbering system is inapplicable to the male gametes because they have no eyespot.

The fate of each gamete and the eyespot can be followed during gamete fusion because FE-SEM images of the size of cell body and the presence or absence of the eyespot are characteristic of female and male gametes. Furthermore, the no. 1 and no. 2 flagella in the female gamete are identifiable, and it is possible to determine the precise orientation of the gametes during fertilization. When both gametes were mixed, the initial cytoplasmic contact and cell fusion between the two gametes usually occurred at the anterior end slightly below the flagellar base (Figs. 4 and 5). In most mating pairs, the gametes fused by folding together in a jackknife-like manner. The female gamete always fused at the anterior left side of the eyespot and the male gamete at one of the cell surfaces perpendicular to the plane of the flagellar beat. This fusion site was positioned between the $2 \mathrm{~s}$ and $1 \mathrm{~d}$ root in the female gamete (Figs. 4 and 5). Thereby, the gamete pairs were situated sideby-side with their longitudinal axes nearly parallel (Fig. 6), as observed previously in this (Enomoto and Ohba 1987) and other species of Caulerpa using light microscopy (Miyake and Kunieda 1937, Goldstein and Morrall 1970). This fusion pattern was observed in 128 mating pairs $(n=131)$ fixed 

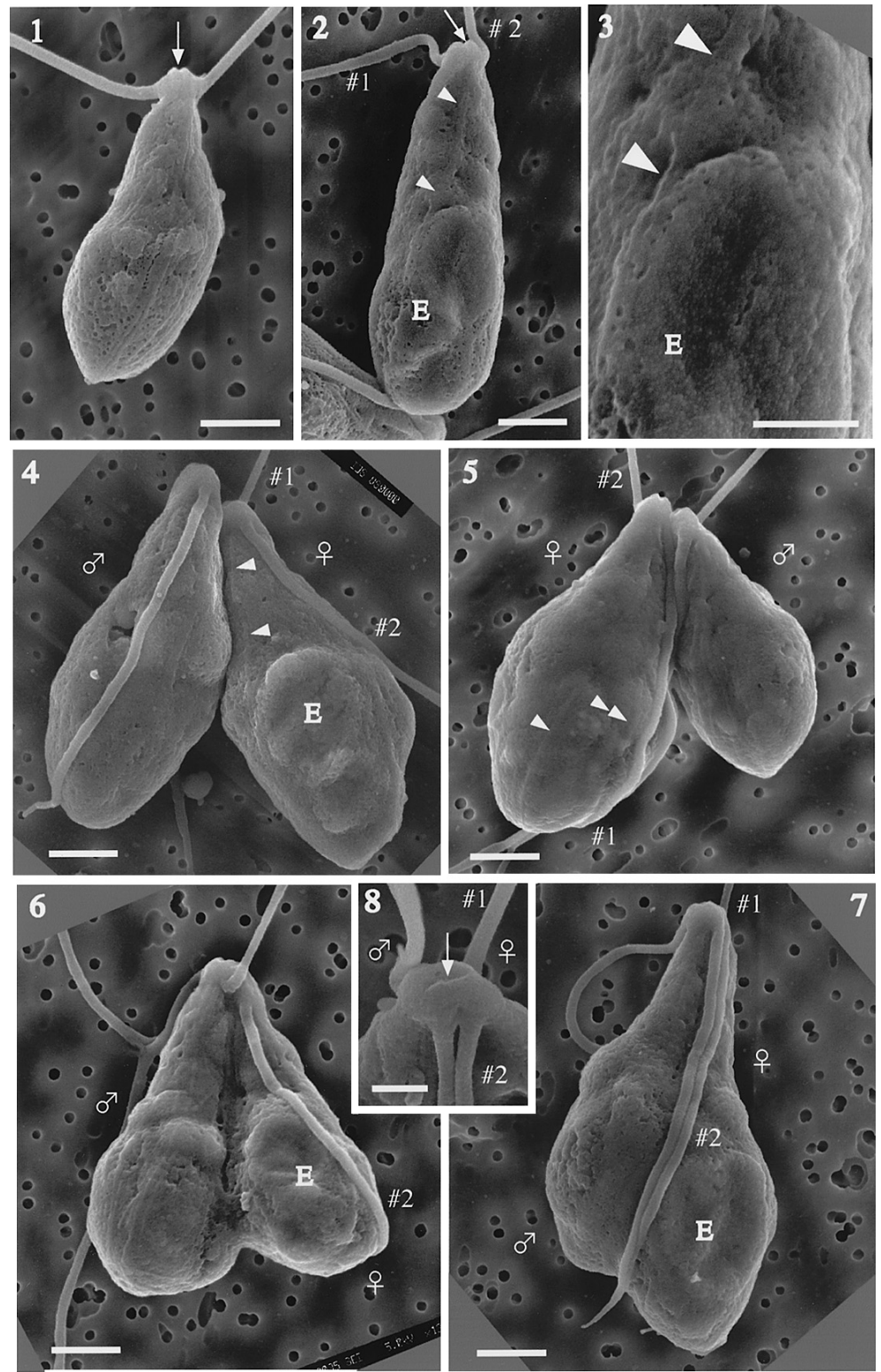

Figs. 1-8. Field emission scanning electron microscope images showing fertilization of gametes of C. racemosa var. laetevirens. 1) Male gamete. 2) Female gamete. 3) Enlarged image of the female gamete's eyespot region. 4) Mating pair viewed from the eyespot side of the female gamete. Attachment of the male gamete ( $\delta$ ) to the anterior left side of the eyespot in the female gamete (\$). 5) Mating pair viewed from the opposite side of the eyespot of the female gamete. 6) Planozygote continuing cell fusion. 7) Planozygote after completing cell fusion. No. 2 flagellum of the female gamete and one male flagellum are directed to the eyespot. 8) Papilla of the planozygote. As the cytoplasmic fusion proceeded, two papillae fused to one papilla and the grooves in the papillae also fused to one long groove. Cells were fixed at $0 \mathrm{~min}(1-3,5,6$ and 8$)$, $1 \mathrm{~min}(7)$ and $5 \mathrm{~min}(4)$ after mixing sediments containing male and female gametes. E: eyespot, §: Male gamete, ( : Female gamete, \#1: no. 1 flagellum. \#2: no. 2 flagellum. Arrows: Groove in the center of the papilla. Arrowheads: 2 s root (Figs. 2-4) or 1s root (Fig. 5). Double arrowheads: $1 \mathrm{~d}$ root. Scale bars, $1 \mu \mathrm{m}$ (Figs. 1, 2, 4-7), $500 \mathrm{~nm}$ (Figs. 3 and 8). 
0-10 min after mixing the gamete sediment. Fusion at the right side of the eyespot in the female gamete was observed in three mating pairs. Gametes fusion was rapid: the stages shown in Figs. 4-6 were apparent in the specimen fixed immediately after mixing gamete sediment.

At a very early stage of gamete adhesion and fusion, papillae from both male and female gametes were easily distinguishable in the gamete pair (Figs. 4 and 5). As the cytoplasmic fusion proceeded from the cell anterior to posterior (Fig. 6), two papillae fused to one papilla and the grooves in the papillae also fused to one long groove (arrow in Fig. 8). Finally, the gametes fused completely (Fig. 7) and one flagellum each from the male and the female gametes became a pair (Fig. 8). In particular, the no. 2 flagellum of the female gamete and one of the male flagella are pointed in the direction of the eyespot (Fig. 7). In contrast to this, the no. 1 flagellum of the female gamete and the other flagellum of the male oriented to the nearly opposite direction to the eyespot: consequently, their mutual angle became ca. $90^{\circ}$.

The present study using FE-SEM revealed the behavior of male and female flagella and the eyespot during fertilization of $C$. racemosa var. laetevirens. These results are consistent with previous observations of $B$. maxima that the female gamete is always fused at the anterior left side of the eyespot with a broader surface of the male gamete (Miyamura et al. 2005). In both species, the cell fusion site of the female gamete probably corresponds to the cell anterior between $1 \mathrm{~d}$ and $2 \mathrm{~s}$ roots. This position is almost identical to the cell fusion site of the female gamete of $U$. arasakii (Miyamura et al. 2003), E. compressa (Miyamura 2003), a sex type of Co. cava (Nakayama and Inouye 2000) and Bo. piliferum (O'Kelly et al. 2004), the mating type minus of Ch. reinhardtii (Holmes and Dutcher 1989) and the mating type plus gamete of N. olivacea (Suda et al. 2004). In contrast to those gametes, the cell fusion site of the opposite sex gamete occupies the opposite positioning in these algae. Therefore, it is likely that two types of gametes, in terms of the position of cell fusion site, exist in these green algae. Nakayama and Inouye (2000) proposed that the presence of opposite positioning of the mating structure in each sex gamete is a universal feature of advanced chlorophytes. Results of this study support their proposal. Furthermore, they indicate that the cell fusion site of the four ulvophycean female gametes (Ulvales: U. arasakii and E. compressa, Caulerpales: B. maxima and C. racemosa var. laetevirens) always occupies the common spatial position. Therefore, it is likely that such features are a characteristic that specifies females in Ulvales and Caulerpales.

In contrast to the algae described above, Goodenough (1991) suggested that both mating types of Ch. eugametos Moewus produce apical papillae that fuse in a far more symmetrical fashion than that observed with $C h$. reinhardtii. Therefore, the cell fusion site of $C h$. eugametos might not occupy an asymmetrical position between the opposite sex gametes because the cytoplasmic bridge forms medially rather than to one side of the basal apparatus. It remains unknown whether $C h$. eugametos is the exceptional case to the asymmetric localization of the cell fusion site in the opposite sex gamete of isogamous and anisogamous algae.

In the planozygote of $C$. racemosa var. laetevirens, two flagella-one each from the male and the female gamete-become a pair; particularly, the no. 2 flagellum of the female gamete and a male flagellum points to the direction of the eyespot (Fig. 7). Such arrangement of flagella in the planozygote has also been observed in B. maxima (Miyamura et al. 2005) and may be important for phototactic steering. The planozygotes of both species show negative phototaxis and migrate away from the light source (Enomoto and Ohba 1987, Miyamura et al. 2005). Phototactic tracking of the algal flagellate is based on the cell's ability to sense the direction of a light beam (Foster and Smyth 1980). As the cells swim, they rotate along their long axis and the eyespot apparatus, as a photoreceptor, scans the light intensity around the cell. In Ch. reinhardtii, two flagella have different $\mathrm{Ca}^{2+}$ sensitivity and the turning mechanism of the cell appears to be inherent to trans and cis flagella (Kamiya and Witman 1984), which correspond respectively to no. 1 and no. 2 flagella. The physiological difference between no. 1 and no. 2 flagella has not been established in ulvophycean algae, 
such inherence of the flagella may be present for a correct turning mechanism of the swarmer. Therefore, co-operating functions of the male and female flagella may be necessary for the correct turning response at the proper point during phototactic steering. This hypothesis seems to explain the flagellar arrangement of the planozygote observed in C. racemosa var. laetevirens and B. maxi$m a$. Finally, it is likely that the cell fusion site of the gamete occupies a specialized position for proper arrangement of flagella and the eyespot in the planozygote, even if one mating partner has no eyespot.

\section{Acknowledgments}

This research was partially supported by a grant-in-aid from the Ministry of Education, Science, Sports and Culture to S. M. (No. 00192766). The author expresses his sincere thanks to Prof. I. Inouye for provision of his freeze-dryer.

\section{References}

Cavalier-Smith, T. 1975. Electron and light microscopy of gametogenesis and gamete fusion in Chlamydomonas reinhardtii. Protoplasma 86: 1-18.

Enomoto, S. and Ohba, H. 1987. Culture studies on Caulerpa (Caulerpales, Chlorophyceae) I. Reproduction and development of C. racemosa var. laetevirens. Jpn. J. Phycol. 35: 167-177.

Friedmann, I., Colwin, A. L. and Colwin, L. H. 1968. Fine-structural aspects of fertilization in Chlamydomonas reinhardi. J. Cell Sci. 3: 115-128.

Fritsch, F. E. 1935. The Structure and Reproduction of the Algae, Vol. I. Cambridge University Press, London.

Foster, K. W. and Smyth, R. D. 1980. Light antennas in phototactic algae. Microbiol. Rev. 44: 572-630.

Gaffal, K. P. and Schneider, G. J. 1978. The changes in ultrastructure during fertilization of the colourless flagellate Polytoma papillatum with special reference to the configural changes of their mitochondria. Cytobiologie 18: 161173.

Goldstein, M. and Morrall, M. 1970. Gametogenesis and fertilization in Caulerpa. Ann. N.Y. Acad. Sci. 175: 660-672.

Goodenough, U. W. 1991. Chlamydomonas mating interactions. In: Dworkins, M. (ed.). Microbial Cell-Cell Interactions. Am. Soc. Microbiol., Washington D.C. pp. 71-112.

— and Weiss, R. L. 1975. Gametic differentiation in Chlamydomonas reinhardtii. III. Cell wall lysis and microfilament-associated mating structure activation in wild-type and mutant strains. J. Cell Biol. 67: 623-637.

— and - 1978. Interrelationships between microtubules, a striated fiber, and the gametic mating structure of Chlamydomonas reinhardtii. J. Cell Biol. 76: 430-438.

Holmes, J. A. and Dutcher, S. K. 1989. Cellular asymmetry in Chlamydomonas. J. Cell Sci. 94: 273-285.

Hori, T. 1981. Ultrastructural studies on nuclear division during gametogenesis in Caulerpa (Chlorophyceae). Jpn. J. Phycol. 29: 163-170.

- 1988. Ultrastructure of gametes and gametic fusion in Bryopsis maxima Okamura (Chlorophyceae). Jpn. J. Phycol. 36: 113-126.

Kamiya, R. and Witman, G. B. 1984. Submicromolar levels of calcium control the balance of beating between the two flagella in demembranated models of Chlamydomonas. J. Cell Biol. 98: 97-107.

Kreimer, G. 2001. Light perception and signal modulation during photoorientation of flagellate. In: Häder, D. P. and Lebert, M. (eds.). Photomovement. Elsevier Science B.V., Amsterdam. pp. 193-227.

Marchant, H. J. and Pickett-Heaps, J. D. 1972. Ultrastructure and differentiation of Hydrodictyon reticulatum. IV. Conjugation of gametes and the development of zygospores and azygospores. Aust. J. Biol. Sci. 25: 279-291.

Melkonian, M. 1980. Flagellar roots, mating structure and gametic fusion in the green alga Ulva lactuca (Ulvales). J. Cell Sci. 46: 149-69.

- 1981. Structure and significance of cruciate flagellar root system in green algae: Female gametes of Bryopsis lyngbyei (Bryopsidales). Helgoländer wiss. Meeresunters. 34: 355-369.

- 1984. Flagellar root-mediated interactions between the flagellar apparatus and cell organelles in green algae. In: W. Wissner, D. G. Robinson and R. C. Starr (eds.). Compartments in Algal Cells and Their Interaction. Springer-Verlag, Berlin. pp. 96-108.

- 1989. Flagellar apparatus ultrastructure in Mesostigma viride (Prasinophyceae). P1. Syst. Evol. 164: 93-122.

— and Robenek, H. 1984. The eyespot apparatus of flagellated green algae: a critical review. Prog. Phycol. Res. 3: 193268. 
Miyaji, K. and Hori, T. 1984. The ultrastructure of gametes of Spongomorpha duriuscula (Acrosiphoniales, Chlorophyta), with special reference to the flagellar apparatus. Jpn. J. Phycol. 32: 307-318.

Miyake, K. and Kunieda, H. 1937. On the sexual reproduction of Caulerpa. Cytologia 8: 205-207.

Miyamura, S. 2003. Eyespot behavior during the fertilization of gametes in ulvalean alga Enteromorpha compressa (Linnaeus) Nees revealed by field emission scanning electron microscopy. Cytologia 68: 173-176.

-, Hori, T. and Nagumo, T. 2003. Eyespot behavior during the fertilization of gametes in Ulva arasakii Chihara (Ulvophyceae, Chlorophyta). Phycol. Res. 51: 143-146.

—, Sakaushi, S., Hori, T., Mitsuhashi, F. and Nagumo, T. 2005. Sex-specific cell surface structure of anisogametes: morphological changes during fertilization of Bryopsis maxima (Ulvophyceae, Chlorophyta) revealed by ultra-high resolution field emission scanning electron microscopy. J. Phycol. 41: 114-125.

Moestrup, Ø. and Hori, T. 1989. Ultrastructure of the flagellar apparatus in Pyramimonas octopus (Prasinophyceae). II. Flagellar roots, connecting fibres, and numbering of individual flagella in green algae. Protoplasma 148: 41-56.

Nakayama, T. and Inouye, I. 2000. Ultrastructure of the biflagellate gametes of Collinsiella cava (Ulvophyceae, Chlorophyta). Phycol. Res. 48: 63-73.

O'Kelly, C. J., Floyd, G. L. and Dube, M. A. 1984. The fine structure of motile cells in the genera Ulvaria and Monostroma, with special reference to the taxonomic position of Monostroma oxyspermum (Ulvophyceae, Chlorophyta). Pl. Syst. Evol. 144: 179-99.

—, Bellows, W. K. and Wysor, B. 2004. Phylogenetic position of Bolbocoleon piliferum (Ulvophyceae, Chlorophyta): Evidence from reproduction, zoospore and gamete ultrastructure, and small subunit rRNA gene sequences. J. Phycol. 40: $209-222$.

Roberts, K. R., Sluiman, H. J., Stewart, K. D. and Mattox, K. R. 1981. Comparative cytology and taxonomy of the Ulvaphyceae. III. The flagellar apparatus of the anisogametes of Derbesia tenuissima (Chlorophyta). J. Phycol. 17: 330-340.

Suda, S., Watanabe, M. M. and Inouye, I. 2004. Electron microscopy of sexual reproduction in Nephroselmis olivacea (Prasinophyceae, Chlorophyta). Phycol. Res. 52: 273-283.

Triemer, R. E. and Brown, R. M., Jr. 1975. The ultrastructure of fertilization in Chlamydomonas moewusii. Protoplasma 84: 315-325. 